\title{
Improving The Mathematical Problem Solving Ability And Mathematical Disposition Using a Problem Posing Approach
}

\author{
Yayu Yusniawati, Heris Hendriana, Rippi Maya
}

\author{
Pascasarjana Pendidikan Matematika, IKIP Siliwangi Bandung \\ yayuyusniawati@gmail.com
}

\begin{abstract}
This research is a quasi experimental research, which aims to examine the achievement and improvement of problem solving skills and mathematical disposition of MA students by using Problem Posing approach. The population in this study is the students of class XI in one MA in Tasikmalaya City. With the sample subject is class XI IIS 1 as the control class and XI IIS 3 as the experimental class which totals the total of 62 students. Data obtained from research instruments in the form of tests (pretest and postes problem solving ability) and nontes (scale of mathematical disposition). After the observation, the data is reviewed and analyzed. Based on the results of research and data processing, obtained: (a) Improvement and achievement of mathematical problem solving ability of MA students whose learning using Problem Posing approach is better than the learning using ordinary learning, and (b) Mathematical disposition of MA students whose learning using Problem Posing approach better than learning using ordinary learning.

Keywords : Problem Solving, dispotition, Problem Posing
\end{abstract}

\section{INTRODUCTION}

Problem solving is an important part of the mathematics curriculum. Because the process of solving mathematical problems is one of the basic mathematical skills that must be mastered by high school students. The importance of possessing such capabilities is reflected in Branca's revelation (Sumarmo, 2013: 445) that mathematical problem solving is one of the important goals in mathematics learning and even the process of solving mathematical problems is the heart of mathematics. And problem solving is one of the goals of learning mathematics according to KTSP.

But the reality that happened in the field just the opposite. Based on observation result of giving diagnostic test by Janayasa (2017) to class X MIA 2 Private High School Al-Ulum Medan on the topic of pythagoras and pythagoras theorem at a special angle, with the number of 2 items about essay, that of 34 students who take the test, obtained the average student score 45.15 (from a scale of 0-100). Or if described, no students get 90-100 points, for students who score 80-89, 75-79 each 1 person, and students who score 61-74 as many as 2 people, while the remaining $3088.24 \%$ got the value $0-60$. From the observation results, it is clear that the mathematical understanding ability of student is very low.

Another important aspect to be considered in the learning process is the attitude or positive views of students to mathematics. This is in accordance with one of the objectives of mathematics learning which is contained in the 2004 curriculum and KTSP that is in addition to having the ability to the ability of mathematics, has an attitude of 
appreciating the usefulness of mathematics in life such as curiosity, attention, interest in learning mathematics and resilience and confidence in mathematical problem solving is also important for students. (Mahmuzah, et al., 2014: 45). Such a condition is called mathematical disposition. However, some research results indicate that there are still many students in Indonesia who do not yet have a positive view of mathematics or have a low mathematical disposition. One of them is Kesumawati research on 297 students from four junior high schools in Palembang. The results showed that the percentage of the average score of disposition score of $58 \%$ was in a low category. (Mahmuzah, et al., 2014: 46)

The low ability of both above and the mathematical disposition should be taken seriously especially by the math teachers. Because the materials in the mathematics course are structured, and the mathematical concepts that are related to each other. This means the students' mathematical knowledge that was previously the basis for further material understanding. So it would be highly recommended to be taken seriously if the child's ability is still low. Because it will affect the ability or knowledge of the other and the next. Early math skills of students assessed will predict the success of future student learning, whether in math or other subjects.

Many factors cause low students' mathematical thinking ability and positive attitude toward mathematics. One way of learning in school may be a bit boring, and does not require active students. Therefore it is necessary an appropriate learning approach so that it can change the learning process and improve learning outcomes. One approach that can realize the learning process and can improve students' mathematical skills, especially the ability to connect and solve mathematical problems, and to grow a positive view of mathematics is a Problem Posing approach.

Problem Posing is the most important core in math discipline. This is in accordances with Susilawati'sopinion (2012: 223) that Problem Posing or filing a problem is an important part of students' math experience, even becoming one constructive suggestion in learning mathematics. Mathematical issues are defined as the reformulation of a series of mathematical problems from the given situation or information. In the implementation of Problem Posing or problem solving is known by three types of models, among others: 1. Situation Problem Posing free, ie students are given life widest opportunity to ask questions, for example, can use the experience of daily life as a reference. 2. Situation Problem Posing semi-structured, ie students are given information openly, then students are asked to ask questions or problems relating to information that has been given and can be associated with a particular concept. 3. Situation Problem Posing structured, students are given the problem and asked to solve the problem, then based on the question the students are asked to ask a new question.

From the above understanding seen that Problem Posing or filing a problem is a development or part of problem solving. Even filing a problem or filing a problem is one step in the problem-solving plan.

The purpose of this study is to examine the achievement and improvement of problem solving skills and mathematical disposition of MA students using Problem Posing approach. 


\section{RESEARCH METHOD}

This research method is quasi-experiment where the writer takes two class as sample subject, with one class has given learning Problem Posing and other class with ordinary learning.

$\mathrm{O} \quad \mathrm{X} \quad \mathrm{O}$

$\mathrm{O} \quad \mathrm{O}$

Where:

O: Pretes $=$ Postest Mathematical Problem Solving Ability

$\mathrm{X}$ : Learning with Problem Posing Approach

: The sampling is not random subjects

The population in this study is the students of class XI in one MA in Tasikmalaya City academic year 2017-2018 consisting of 7 classes, including 4 classes of XI IIS and 3 classes MIA. With the sample, subjects are two classes, namely class XI IIS 1 and XI IIS 3. Class XI IIS 1 as a control class by using normal learning and class XI IIS 3 as an experimental class with learning by using Problem Posing approach.

To obtain research data made research instrument. The instrument consisted of pretest test and posttest test and non-test in the form of a mathematical disposition scale questionnaire.

\section{RESULTS AND DISCUSSION}

Based on pretest data processing, posttest mathematical problem solving ability (MPSA) and mathematical disposition (MD) in the experimental class (PP) and control class $(\mathrm{PB})$ obtained the mean score $(\mathrm{x} \overline{)}$ following percentage of ideal score $(\%)$, standard deviation ( $\mathrm{s}$ ). can be seen in the following table:

Table 1. Recapitulation of Mathematical Problem Solving Ability Test Results

\begin{tabular}{|c|c|c|c|c|c|c|c|c|c|}
\hline \multirow{2}{*}{$\begin{array}{c}\text { Mathematical } \\
\text { Ability }\end{array}$} & \multirow{2}{*}{$\begin{array}{c}\overline{\boldsymbol{x}} \\
\text { and } \\
\mathrm{s}\end{array}$} & \multicolumn{4}{|c|}{ Experiment (PP) } & \multicolumn{4}{|c|}{ Control (PB) } \\
\hline & & $\begin{array}{l}\text { Pretest } \\
(\%)\end{array}$ & $\begin{array}{c}\text { Posttest } \\
(\%)\end{array}$ & Gain & $\mathrm{N}$ & $\begin{array}{c}\text { Pretest } \\
(\%)\end{array}$ & $\begin{array}{c}\text { Postest } \\
\text { (\%) }\end{array}$ & Gain & $\mathrm{N}$ \\
\hline \multirow[t]{3}{*}{ MPSA } & $\bar{x}$ & 8,42 & 38,39 & 0,58 & 31 & 8,42 & 30,13 & 0,42 & 31 \\
\hline & $\%$ & 14,03 & 63,98 & 0,97 & & 14,03 & 50,22 & 0,70 & \\
\hline & $\mathrm{S}$ & 1,63 & 7,59 & 0,14 & & 1,46 & 5,00 & 0,09 & \\
\hline
\end{tabular}

Maximum Score MPSA $=60$

Based on the above table, it is seen for the achievement and improvement of mathematical problem solving ability (MPSA) of MA students whose learning using Problem Posing approach and ordinary learning show difference. Overall, the 
achievement of mathematical problem solving ability (MPSA) students using Problem Posing approach with $=38,39(63,98 \%)$ is higher than the learning using ordinary learning with $=30,13(50,22 \%)$ and improvement of problem solving ability of mathematics students using Problem Posing approach with $=0.58$ higher than the learning using ordinary learning with $=0.42$. To see the significance, can be seen from the following table:

Table 2. Mathematical Problem Solving Ability (MPSA) Test

\begin{tabular}{|c|c|c|c|c|c|c|}
\hline \multirow[t]{2}{*}{ KELAS } & \multicolumn{2}{|c|}{ PRETEST } & \multicolumn{2}{|c|}{ POSTTEST } & \multicolumn{2}{|c|}{ N-GAIN } \\
\hline & $\bar{x}$ & $\begin{array}{l}\text { Sig (2- } \\
\text { tailed) }\end{array}$ & $\bar{x}$ & $\begin{array}{l}\text { Sig (1- } \\
\text { tailed) }\end{array}$ & $\bar{x}$ & $\begin{array}{l}\text { Sig (1- } \\
\text { tailed) }\end{array}$ \\
\hline Experiment (PP) & 8,42 & .872 & 38,39 & .000 & 0,53 & .000 \\
\hline Control (PB) & 8,42 & & 30,13 & & 0,42 & \\
\hline
\end{tabular}

Based on the data in the table above shows that Sig. (1-tailed) is $0.000<0.05$ then $\mathrm{H} 0$ is rejected which means the achievement of mathematical problem solving ability of MA students whose learning using Problem Posing approach is better than the learning using ordinary learning. And Based on the data on that seen that Sig. (1-tailed) is 0,000 $<0,05$ then $\mathrm{H} 0$ is rejected which means improvement of mathematical problem solving ability of MA students whose learning using Problem Posing approach is better than the learning using ordinary learning.

In addition, siswapun showed a positive attitude towards the approach of Problem Posing than usual learning, as in the table below.

Table 3. Recapitulation of Mathematical Dispotition Test Results

\begin{tabular}{|c|c|c|c|c|c|}
\hline \multirow{2}{*}{$\begin{array}{l}\text { Mathematical } \\
\text { Ability }\end{array}$} & \multirow{3}{*}{$\begin{array}{c}\overline{\boldsymbol{x}} \\
\text { and } \\
\mathrm{s}\end{array}$} & \multicolumn{2}{|c|}{ Experiment (PP) } & \multicolumn{2}{|c|}{ Control (PB) } \\
\hline & & Posttest & $\mathrm{N}$ & Postest & $\mathrm{N}$ \\
\hline & & & & & \\
\hline \multirow[t]{4}{*}{ MD } & $\bar{x}$ & 81,26 & \multirow[t]{3}{*}{31} & 71,06 & \multirow[t]{3}{*}{31} \\
\hline & $\%$ & 78,13 & & 68,33 & \\
\hline & $\mathrm{s}$ & 7,98 & & 8,17 & \\
\hline & \multicolumn{5}{|c|}{ Maximum Score MD = 104} \\
\hline
\end{tabular}

Visible to the achievement of mathematical disposition (MD) of MA students whose learning using Problem Posing approach and ordinary learning show differences. Overall, the achievement of mathematical disposition (MD) of students using Problem Posing approach with $=81.26(78.13 \%)$ is higher than that of learning using ordinary learning with $=71.06(68.33 \%)$. To see the significance, can be seen from the following table:

Table of Mathematical Dispotition

\begin{tabular}{ccc}
\hline Class & \multicolumn{2}{c}{ POSTTEST } \\
\cline { 2 - 2 } & $\bar{x}$ & Sig (1-tailed) \\
\hline Experiment (PP) & 81,26 & .000 \\
\hline Control (PB) & 71,06 &
\end{tabular}


Based on the data in the table above shows that Sig. (1-tailed) is $0,000<0.05$ then $\mathrm{HO}$ is rejected which means the level of mathematical disposition of MA students whose learning using Problem Posing approach is better than students whose learning is using ordinary learning.

\section{DISCUSSION}

Based on the results of the research, students' mathematical problem solving skills have improved, and the achievement is better than the students using ordinary learning.

The improvement of these two capabilities is similar to that of Kadir (2011) on the implementation of problem posing learning approaches and their impact on learning outcomes. The results of his research revealed the approach of problem posing significantly affect the results of learning mathematics. And he argues that learning mathematics with problem posing approach is able to make students active and creative, visible from the ability of students to develop their own math problems, cultivate and explore existing information and solve math problems that can be solved.

\section{CONCLUSION}

From the results of research and discussion of problem solving, and mathematical disposition of students using Problem Posing approach and ordinary learning, which has been stated in the previous chapter, then obtained some conclusions as follows:

1. The achievement of mathematical problem solving ability of MA students whose learning using Problem Posing approach is better than the learning using ordinary learning.

2. Improved mathematical problem-solving skills of MA students whose learning using Problem Posing approach is better than that of learning using ordinary learning.

3. The mathematical disposition of MA students whose learning using the Problem Posing approach is better than that of learning using ordinary learning.

\section{REFERENCES}

Janayasa, H.F. (2017). "Perbedaan Kemampuan Pemecahan Masalah Matematika Menggunakan Model Problem Based Learning dengan Model Group Investigation". SEMNASTIKA UNIMED. ISBN: 978-602-17980-9-6

Kadir. (2011). "Impelementasi Pendekatan Pembelajaran Problem Posing dan Pengaruhnya Terhadap Hasil Belajar Matematika". Jurnal Pendidikan dan Kebudayaan. Vol. 17-No.2, 206.

Mahmuzah, R., Ikhsan, M., \& Yusrizal (2014). "Peningkatan Kemampuan Berpikir Kritis dan Disposisi Matematis Siswa SMP dengan Menggunakan Pendekatan Problem Posing”. Jurnal Didaktik Matematika. Vol. 1-No. 2, 45-46.

Sumarmo, U. (2013). Kumpulan Makalah Berpikir dan Disposisi Matematik serta Pembelajarannya. Bandung: Tidak Diterbitkan.

Susilawati, W. (2012). Belajar dan Pembelajaran Matematika. Bandung: CV. Insan Mandiri. 